\title{
Mechanisms of Nitric Oxide-mediated Neurotoxicity in Primary Brain Cultures
}

\author{
Valina L. Dawson, ${ }^{1}$ Ted M. Dawson,, ${ }^{2,3}$ Duane A. Bartley, ${ }^{2}$ George R. Uhl, ${ }^{1,2.3}$ and Solomon H. Snyder ${ }^{2,4}$ \\ 'National Institute on Drug Abuse, Addiction Research Center, Laboratory of Molecular Neurobiology, Baltimore, Maryland \\ 21224 and Departments of ${ }^{2}$ Neuroscience, ${ }^{3}$ Neurology, ${ }^{4}$ Pharmacology and Molecular Sciences, and Psychiatry, The \\ Johns Hopkins University School of Medicine, Baltimore, Maryland 21205
}

In addition to mediating several physiological functions, nitric oxide (NO) has been implicated in the cytotoxicities observed following activation of macrophages or excess stimulation of neurons by glutamate. We extend our previous observations of glutamate-stimulated, NO-mediated neurotoxicity in primary cultures of rat fetal cortical, striatal, and hippocampal neurons. Neurotoxicity elicited by either NMDA or sodium nitroprusside (SNP) exhibits a similar concentration-effect relationship and time course. The concentrationeffect curve of NMDA-induced neurotoxicity is shifted to the right in the presence of nitro-L-arginine and farther to the right in arginine-free media. The rank order of potency of several NO synthase (NOS) inhibitors in preventing neurotoxicity is the same as the rank order of these compounds in inhibiting NOS, and this inhibition is stereospecific. NMDA neurotoxicity is also prevented by flavoprotein inhibitors and calmodulin inhibitors, fitting with the roles of flavoproteins and calmodulin as NOS regulators. 8-Bromo-cGMP and guanylyl cyclase inhibitors do not affect neurotoxicity, while superoxide dismutase attenuates neurotoxicity. NOS neurons appear to be the source of neurotoxic NO in culture, as lesions of these neurons with $\mathbf{2 0} \mu \mathrm{M}$ quisqualate diminish subsequent NMDA neurotoxicity. Moreover, NMDA neurotoxicity develops over time in culture coincident with the expression of NOS. Immunohistochemical localization of NOS in cultures and intact brain demonstrates widespread distribution of the cell processes suggesting that NOS neurons contact the majority of cortical neurons and so could mediate widespread neurotoxicity.

[Key words: NADPH-diaphorase, glutamate, NMDA, nitric oxide synthase, excitotoxicity, neurodegeneration]

Besides its roles as endothelial-derived relaxing factor (Furchgott, 1990; Ignarro, 1990; Moncada et al., 1991) and a mediator

\footnotetext{
Reccived Oct. 5, 1992; revised Jan. 4, 1993; accepted Jan. 11, 1993.

We thank Dr. Charles E. Spivak for performing the electrophysiologic experiments. This work was supported by USPHS Grants MH-1850I and DA-00266, Contract DA 271-90-7408, and Research Scientist Award DA-00074 to S.H.S., and NIGMS Pharmacology Research Associate Training Program and an Intramural Research Training Award (IRTA) from the NIH to V.L.D. T.M.D. is a Pfizer postdoctoral fellow and is supported by grants from the American Academy of Neurology, the French Foundation for Alzheimer's Research, the DANA Foundation, and USPHS CIDA NS 01578-01. We gratefully acknowledge support of the W. M. Keck Foundation.

Correspondence should be addressed to Solomon H. Snyder, Departments of Neuroscience and Pharmacology and Molecular Sciences, 725 North Wolfc Street, Baltimore, MD 21205.

Copyright (C) 1993 Society for Neuroscience $0270-6474 / 93 / 132651-11 \$ 05.00 / 0$
}

of macrophage cytotoxicity (Hibbs et al., 1987; Marletta, 1989; Ignarro, 1990), nitric oxide (NO) appears to be a neuronal messenger in the brain and PNS, satisfying many criteria of a neurotransmitter (Garthwaite, 1991; Snyder and Bredt, 1991; Dawson et al., 1992; Snyder, 1992). NO synthase (NOS) is localized to the same discrete neuronal populations in the brain that stain for NADPH-diaphorase (T. M. Dawson et al., 1991; Hope et al., 1991), a histochemical marker for neurons that resist certain forms of neurotoxicity (Beal et al., 1986; Koh et al., 1986; Koh and Choi, 1988). NOS catalytic activity accounts for NADPHdiaphorase staining, as transfection of human kidney 293 cells with NOS cDNA provides NADPH-diaphorase and NOS staining in the same proportions as in neurons (T. M. Dawson et al., 1991).

Glutamate neurotoxicity elicited via NMDA subtypes of glutamate receptors appears to mediate much of the neurotoxicity in focal ischemia, as NMDA antagonists block such neurotoxicity (Choi, 1988, 1990). Glutamate ncurotoxicity may also play a role in neurodegenerative diseases such as Alzheimer's and Huntington's discases (Choi, 1988; Meldrum and Garthwaite, 1990). At NMDA receptors, glutamate triggers the opening of cation-permeable channels. The entry of calcium through these channels into cells stimulates NOS activity (Bredt and Snyder, 1989) by binding to calmodulin, which is a cofactor for NOS (Bredt and Snyder, 1990).

Recently we demonstrated that NMDA neurotoxicity is attenuated in primary cerebral cortical cultures by the coapplication of NOS inhibitors or removal of the precursor of NO, L-arginine (V. L. Dawson et al., 1991; T. M. Dawson et al., 1993). These protective effects are reversed by addition of excess L-arginine. In addition, sodium nitroprusside (SNP), which generates NO, mimics NMDA-induced neurotoxicity. Both SNP and NMDA neurotoxicities are also blocked by hemoglobin, which binds NO. Together, these results implicate NO as a potential mediator of NMDA neurotoxicity. In the present study we examine the detailed mechanisms regulating NO mediation of glutamate neurotoxicity.

\section{Materials and Methods \\ Cell cultures}

Primary cell cultures were prepared from fetal rats (gestation day 14 for cortex and caudate-putamen cultures, gestation day 17 for hippocampal cultures). The various brain regions were dissected under a microscope, incubated for $20 \mathrm{~min}$ in $0.027 \%$ trypsin/saline solution $(5 \%$ phosphatebuffered saline, $40 \mathrm{~mm}$ sucrose, $30 \mathrm{~mm}$ glucose, $10 \mathrm{~mm}$ HEPES, $\mathrm{pH}$ 7.4), and transferred to modified Eagle's medium (MEM), $10 \%$ horse scrum, $10 \%$ fetal bovine serum, $2 \mathrm{~mm}$ glutamine. Cells were dissociated by trituration, counted, and plated in $15 \mathrm{~mm}$ multiwell (Nunc) plates 
coated with polyornithine at a density of $3-4 \times 10^{5}$ cells per well. Four days after plating, the cells were treated with $10 \mu \mathrm{g} / \mathrm{ml}$ of $5-$ fluoro- 2 deoxyuridine for $3 \mathrm{~d}$ to inhibit proliferation of non-neuronal cells. Cells were maintained in MEM, 5\% horse serum, 2 mM glutamine in $8 \%$ $\mathrm{CO}_{2}$, humidified, $37^{\circ} \mathrm{C}$ atmosphere. The medium was changed twice a week. Mature neurons (more than $21 \mathrm{~d}$ in culture) were used in all cxperiments except for the experiments examining the ontogeny and development of NMDA neurotoxicity in relation to NMDA currents and expression of NOS. In the mature cultures the percentage of neurons is approximately $70-90 \%$ of the total number of cells as assessed by neuron-specific enolase (NSE) and glial fibrillary acidic protein (GFAP) immunocytochemical staining of neurons and astrocytes, respectively (V. L. Dawson, T. M. Dawson, D. A. Bartley, G. R. Uhl, and S. H. Snyder, unpublished observations).

\section{Cytotoxicity}

Cells were exposed to test solutions as previously described (V. L. Dawson et al., 1991). The cells were washed three times with a Tris-buffered control salt solution (CSS) containing $120 \mathrm{~mm} \mathrm{NaCl}, 5.4 \mathrm{~mm} \mathrm{KCl}, 1.8$ $\mathrm{mm} \mathrm{CaCl}, 25 \mathrm{~mm}$ Tris- $\mathrm{HCl}$, and $15 \mathrm{~mm}$ glucose, pH 7.4 at room temperature. Except for exposures to kainate, all other drug solutions were applied to the cells for $5 \mathrm{~min}$ and then washed away with CSS replaced with MEM containing $21 \mathrm{~mm}$ glucose and the cells were put back in the incubator. Exposures to kainate were performed in MEM, $21 \mathrm{~mm}$ glucose for $24 \mathrm{hr}$ in the incubator. Twenty to twenty-four hours after exposure to drug solutions the cells were exposed to $0.4 \%$ trypan blue in CSS to stain the residue of nonviable cells. Two to four photoprints at 10-20x were made of cach well. Viable versus nonviable cells were counted, with approximately 500-1500 cells counted per well. At least two separate experiments utilizing four separate wells were performed so that a minimum of $4000-12,000$ neurons were counted for each data point. Ten percent of the photomicrographs were counted by an additional observer blinded to the arrangement of photomicrographs, study design, and treatment protocol. An inter-rater reliability of greater than $90 \%$ was consistently observed for the cell counting. In some of the experiments photomicrographs were made before and after treatment using a transparent grid at the bottom of each culture plate. Viable and nonviable neurons in identical fields were counted by an observer blinded to study design and treatment protocol. Under the conditions used for assessment of neurotoxicity, no appreciable loss of neurons after the various treatment conditions was identified when comparing "before" and "after" photomicrographs. Furthermore, there was no significant difference between the results obtained with either method of assessing neurotoxicity.

\section{Electrophysiology}

Cortical neurons in sister cultures were voltage clamped by whole-cell patch clamp as previously described (Hamill et al., 1981). Celts were bathed in an extracellular solution containing $137 \mathrm{~mm} \mathrm{NaCl}, 2.5 \mathrm{~mm}$ $\mathrm{KCl}, 2 \mathrm{~mm} \mathrm{CaCl}, 10 \mathrm{~mm}$ HEPES, and $10 \mathrm{~mm}$ glucose, pH 7.3. Micropipettes were pulled from $1.5 \mathrm{~mm}$ fiber-fill capillary tubing and filled with an intracellular solution containing $140 \mathrm{~mm} \mathrm{KCl}, 2 \mathrm{~mm} \mathrm{MgCl}_{2}, 11$ mM EGTA, $1 \mathrm{~mm} \mathrm{CaCl}$, and $10 \mathrm{~mm}$ HEPES, pH 7.2. Micropipette tip internal diameters were approximately $1 \mu \mathrm{m}$ with resistances of approximately $7 \mathrm{M} \Omega$. The target cell was microsuperfused (Demirgoren et al., 1991) with extracellular solution containing $0.3 \mu \mathrm{M}$ tetrodotoxin with or without $200 \mu \mathrm{M}$ NMDA, $10 \mu \mathrm{M}$ glycine. Recordings were made in the whole-cell voltage-clamp mode (Hamill et al., 1981) using a List EPC-7 amplifier (Adams and List Associates, Ltd., Great Neck, NY). Signals were recorded simultaneously on an FM tape recorder and a Gould strip chart recorder.

\section{Diaphorase staining}

Cells were washed three times with CSS and fixed for $30 \mathrm{~min}$ at $4^{\circ} \mathrm{C}$ in a $4 \%$ paraformaldehyde (PF), $0.1 \mathrm{M}$ phosphate buffer (PB). The PF solution was washed away with Tris-buffered saline (TBS) $50 \mathrm{~mm}$ Tris$\mathrm{HCl}, 1.5 \% \mathrm{NaCl}, \mathrm{pH} 7.4$. The reaction solution containing $1 \mathrm{~mm}$ NADPH, $0.2 \mathrm{~mm}$ nitroblue tetrazolium, $0.2 \%$ Triton $\mathrm{X}-100$ (TX-100) $1.2 \mathrm{~mm}$

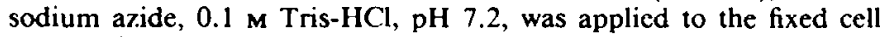
cultures for $1 \mathrm{hr}$ at $37^{\circ} \mathrm{C}$. The reaction was terminated by washing away the reaction solution with TBS. All diaphorase-positive cells in each well were counted utilizing an inverted microscope.

\section{NOS immunohistochemistry.}

Cells were washed threc times with CSS and fixed for 30 min at $4^{\circ} \mathrm{C}$ in a 4\% PF, 0.1 м PB. The cells were then washed with TBS. The cells were then permeabilized with $0.2 \%$ TX-100 in TBS for $5 \mathrm{~min}$, followed by blocking with $4 \%$ normal goat serum (NGS), $0.1 \%$ TX-100 in TBS for $1 \mathrm{hr}$. This was followed by incubating the cells with affinity-purified anti-NOS antibodies overnight at $4^{\circ} \mathrm{C}$ (Bredt et al., 1990, 1991; T. M. Dawson et al., 1991). The cells were then rinsed three times in TBS for $10 \mathrm{~min}$ each. After rinsing, the cells were incubated with biotin-conjugated secondary antibody (goat anti-rabbit; Vector Laboratories) for $1 \mathrm{hr}$ at room temperature in $1.5 \%$ NGS, TBS, $0.1 \%$ TX-100. After an additional three washes in TBS, the cells were incubated with an avidinbiotin-peroxidase complex (1:50; Vector Elite, Vector Laboratories) in TBS for $45 \mathrm{~min}$ at room temperature. The cells were again rinsed three times for $10 \mathrm{~min}$ each in TBS and were developed with a substrate solution consisting of $0.01 \% \mathrm{H}_{2} \mathrm{O}_{2}$ and $0.5 \mathrm{mg} / \mathrm{ml}$ diaminobenzidine in TBS. Cells were then rinsed in TBS containing $0.02 \%$ sodium azide. All NOS-positive cells in each well were counted utilizing an invertcd microscope.

Immunohistochemistry for NSE (Incstar) and GFAP (Incstar) was performed as described above with substitution of NSE antiserum or GFAP antiserum for anti-NOS antibody.

NOS immunohistochemistry of rat brain was performed as described (Bredt et al., 1990, 1991; T. M. Dawson et al., 1991). Briefly, male Sprague-Dawley rats $(150-250 \mathrm{gm})$ were perfused with phosphate-buffered saline (PBS; $50 \mathrm{~mm} \mathrm{~PB}, 0.9 \% \mathrm{NaCl}, \mathrm{pH} 7.4,4^{\circ} \mathrm{C}$ ) followed by perfusion with $4 \% \mathrm{PF}$ in $0.1 \mathrm{M} \mathrm{PB}, \mathrm{pH} 7.4,4^{\circ} \mathrm{C}$. The brains were removed and postfixed for $2 \mathrm{hr}$ in $4 \% \mathrm{PF}$ in $0.1 \mathrm{M} \mathrm{PB}, \mathrm{pH} 7.4,4^{\circ} \mathrm{C}$. This was followed by cryoprotection in $20 \%$ glycerol in $0.1 \mathrm{M} \mathrm{PB}, \mathrm{pH} 7.4,4^{\circ} \mathrm{C}$ $(\mathrm{v} / \mathrm{v})$ overnight. Thick $(40 \mu \mathrm{m})$ sections were cut with a sliding microtome (Microm) and sections were stained with the anti-NOS antibody as described for the cortical cultures.

\section{Measurement of NOS catalytic activity.}

Mature cortical neurons were treated with $500 \mu \mathrm{M}$ NMDA for 5 min utilizing identical conditions as in the cytotoxicity assay. At $2,4,8$, and $24 \mathrm{hr}$ after NMDA administration, the cells were scraped from the culture wells and homogenized in $50 \mathrm{~mm}$ Tris- $\mathrm{HCl}$ buffer containing 1 mM EDTA and I mM EGTA, pH 7.4. Cortical cultures were also treated with $3.5 \mathrm{ng} / \mathrm{ml}$ lipopolysaccharide (LPS) and $5 \mathrm{U} / \mathrm{ml} \gamma$-interferon for $24 \mathrm{hr}$ and then homogenized in the above buffer. NOS catalytic activity was assessed by measuring the conversion of ${ }^{3} \mathrm{H}$-arginine to ${ }^{3} \mathrm{H}$-citrulline as previously described (Bredt and Snyder, 1989, 1990) in the presence and absence of calcium as well as NADPH. After incubation for $15 \mathrm{~min}$ at room temperature, the assays were quenched with two $2 \mathrm{ml}$ aliquots of $20 \mathrm{~mm}$ HEPES, pH 5.5, $2 \mathrm{~mm}$ EDTA applied to $1 \mathrm{ml}$ columns of Dowex AG50WX-8 $\left(\mathrm{Na} \cdot\right.$ form). ${ }^{3} \mathrm{H}$-citrulline was quantified by liquid scintillation counting of the $4 \mathrm{ml}$ flow through. All values were compared to control vehicle-treated cells.

\section{Materials}

NMDA and MK801 were purchased from Research Biochemicals Incorporated. A23187 was obtained from Calbiochem. Diphenyleniodonium (DPI) was obtained from Kodak. DPI and A23187 were dissolved in dimethyl sulfoxide (DMSO) and diluted to a final concentration of $0.1 \%$ DMSO. All other compounds were dissolved in CSS. LPS was obtained from GIBCO, and recombinant murine $\gamma$-interferon, from Upstate Biotechnology, Inc. ${ }^{3} \mathrm{H}$-arginine was obtained from New $\mathrm{En}$ gland Nuclear/DuPont. L-Iminoethylornithine (NIO) was a generous gift from Dr. Salvador Moncada, The Wellcome Foundation, Ltd.; SIN-1 (3-morpholino-sydnonimine-hydrochloride) and C88-3934 were gifts of Cassella AG. Unless otherwise noted, all other chemicals were purchased from Sigma (St. Louis, MO). Reduced hemoglobin was prepared as described by Martin et al. (1985). Solutions of SNP, SIN-1, and C883934 were prepared in the dark immediately before application to the cultures to minimize photolysis. Cell culture media and arginine-free media were obtained from GIBCO. Arginine can be depleted from cultures by growing them in arginine-free media for $24 \mathrm{hr}$ in the presence of glutamine, which inhibits argininosuccinate synthetase (Sessa et al., 1990). Cortical neurons remain viable in arginine-free media for up to $72 \mathrm{hr}$ (Dawson, Dawson, Bartley, Uhl, and Snyder, unpublished observations). 


\section{Results}

Effects of NOS inhibitors on NMDA neurotoxicity. To evaluate the relationship of NO generation to NMDA neurotoxicity, we examined concentration-response relationships and the time course of cell death for both SNP and NMDA in cortical cultures (Fig. 1). The shapes of the concentration-response curves for NMDA and SNP are essentially the same. Neurotoxicity increases from about $10 \%$ to more than $80 \%$ cell death with both SNP and NMDA over about 2 orders of magnitude, suggesting the absence of cooperativity. The time course of toxicity for NMDA and SNP is comparable with minimal effects over the first $4 \mathrm{hr}$ proceeding to almost maximal neurotoxicity after 12 $\mathrm{hr}$. This lag phase, following a brief $5 \mathrm{~min}$ application of NMDA, described previously by others (Choi, 1987; Choi et al., 1988; Koh et al., 1990), is relativcly unique to this form of neurotoxicity; for example, it is not evident with kainate toxicity. Thus, the close similarity of SNP and NMDA neurotoxic effects both in concentration-response relationships and time course is consistent with NO mediating NMDA toxicity. However, since SNP breaks down to $\mathrm{NO}$ and $\mathrm{Fe}\left(\mathrm{CN}_{5}\right)^{2-}$ it is possible that SNP kills neurons by a process unrelated to NO, as SNP has nonspecific actions that include blockade of NMDA receptors (East et al., 1991; Kiedrowski et al., 1991; Manzoni et al., 1992a). It has been proposed that the nonspecific action is due to the $\mathrm{Fe}\left(\mathrm{CN}_{5}\right)^{2-}$ moiety of SNP, as $\mathrm{K}_{4}\left[\mathrm{Fe}(\mathrm{CN})_{6}\right]$ had similar effects (East et al., 1991; Kiedrowski et al., 1991, 1992; Manzoni et al., 1992a). To determine whether SNP toxicity could involve $\mathrm{Fe}\left(\mathrm{CN}_{5}\right)^{2-}$, we applied $\mathrm{K}_{4}\left[\mathrm{Fe}(\mathrm{CN})_{6}\right]$ at concentrations up to 3 mM under identical exposure conditions and found no significant neuronal injury. Interestingly, concentrations as low as 100 $\mu \mathrm{M}_{4}\left[\mathrm{Fc}(\mathrm{CN})_{6}\right]$ are completely neuroprotective against NMDA toxicity (data not shown). Further evidence that NO is neurotoxic is that SIN-1, another agent that releases $\mathrm{NO}$ in aqueous solutions, also elicits neuronal injury, while C88-3934, a structurally rclated compound that does not release $\mathrm{NO}$, does not elicit neuronal toxicity (data not shown). Other NO releasers elicit neurotoxicity in cortical cultures (Lustig et al., 1992b), fitting with our observations.

Confirming our previous observations (V. L. Dawson et al., 1991), the NOS inhibitor $N^{\mathrm{C}}$-nitro-L-arginine (N-Arg) blocks NMDA cell death (Fig. 2). The concentration-response relationship for NMDA is shifted to the right in the presence of 100 $\mu \mathrm{M}$ N-Arg. This protective effect is only overcome by an NMDA concentration of $7 \mathrm{~mm}$. Arginine-free medium also attenuates NMDA neurotoxicity, producing a rightward shift of the NMDA concentration-response curve. Arginine-free medium has a greater effect on NMDA neurotoxicity than coapplication of 100 $\mu_{M}$ N-Arg, a maximally effective concentration in culture. At 7 mM NMDA, neither N-Arg nor arginine-free medium prevented toxicity. Additionally, the NMDA antagonist MK801, which blocks the neurotoxicity of $1 \mathrm{mM}$ NMDA, fails to block the neurotoxicity elicited by $7 \mathrm{mM}$ NMDA. Thus, the toxicity observed at concentrations of NMDA at or exceeding $7 \mathrm{mM}$ NMDA appears not to involve NMDA receptors or NO.

Previously we reported that a single high concentration of L-arginine can reverse the protective effects of N-Arg (V. L. Dawson et al., 1991). In the present study we have explored a detailed concentration-response relationship for $\mathbf{L}$-arginine (Fig. 2 , inset). Half-maximal reversal of the protective effects of arginine-free medium is evident at $25 \mu \mathrm{M}$ L-arginine, with maximal effects near $100 \mu \mathrm{M}$.

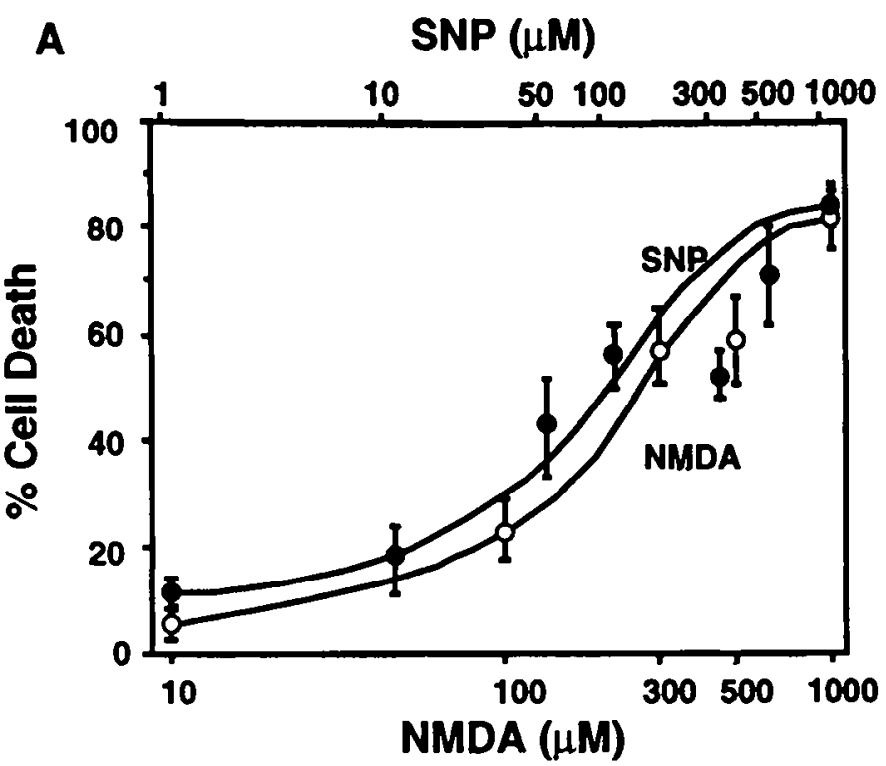

B

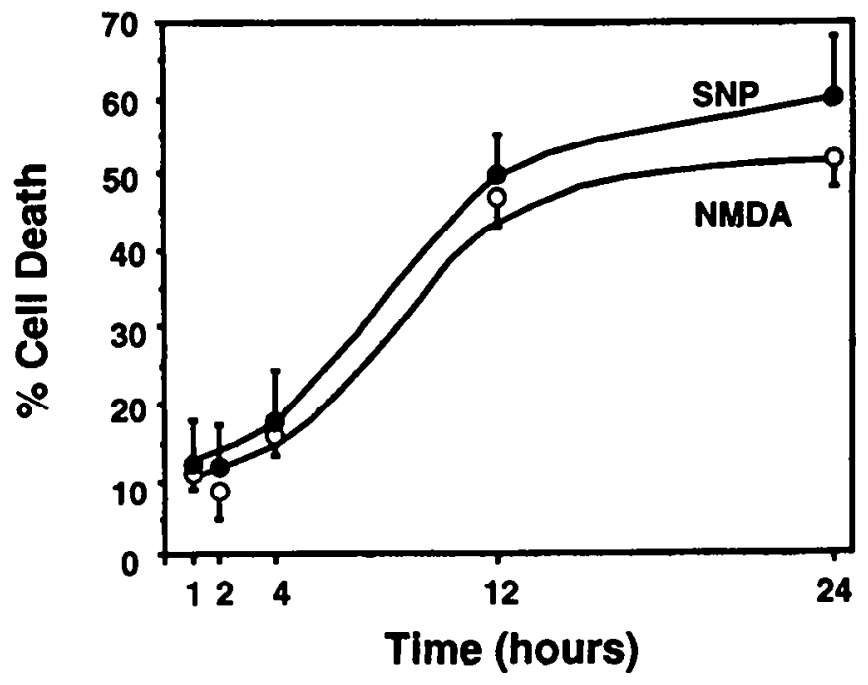

Figure 1. Dose dependence and time course of NMDA and SNP neurotoxicity. In primary cortical cultures SNP elicits cell death in a dosedependent fashion that parallels NMDA dose dependence $(A)$. $\mathrm{Fe}\left(\mathrm{CN}_{5}\right)^{2-}$, produced when SNP releases NO, does not elicit toxicity when applied to cells in concentrations equivalent to SNP (data not shown). The time course of cell death following a $5 \mathrm{~min}$ application of SNP mimics NMDA cell death $(B)$. Each data point represents the mean \pm SEM of at least two separate experiments in which at least four wells were treated with the various agents per experiment; 500-1500 neurons were counted per well.

Various arginine derivatives differ in their potencies as NOS inhibitors as well as their selectivity for brain as compared to macrophage NOS (Moncada et al., 1991). Accordingly, we examined concentration-responsc relationships for a series of NOS inhibitors (Fig. 3). N-Arg is most potent with $50 \%$ protective effects at $20 \mu \mathrm{M}$. $N$-methyl-arginine (NMA), a weaker inhibitory of brain NOS than N-Arg, is about one-eighth as potent as N-Arg in protecting against toxicity. NIO, which has a greater affinity for macrophage NOS and has intermediate potency between N-Arg and NMA in inhibiting brain NOS (McCall et al., 1991), also displays intermediate potency in blocking NMDA toxicity. 
Figure 2. NMDA neurotoxicity is inhibited by $\mathrm{N}$-Arg or arginine-free media $(A F-M E M)$. The dose-response of cortical cultures to increasing concentrations of NMDA is shifted to the right by N-Arg and further to the right in arginine-free media with a more than 20 -fold increase in the $50 \%$ lethal concentration of NMDA. Adding graded concentrations of $\mathrm{L}$-arginine to $300 \mu \mathrm{M}$ NMDA in arginine-free media reveals a requirement for L-arginine with an

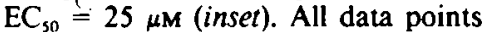
represent the mean \pm SEM of at least two separate experiments in which at least four wells were treated with various agents per experiment; $500-1500$ neurons were counted per well. The concentration of NMDA is molar.

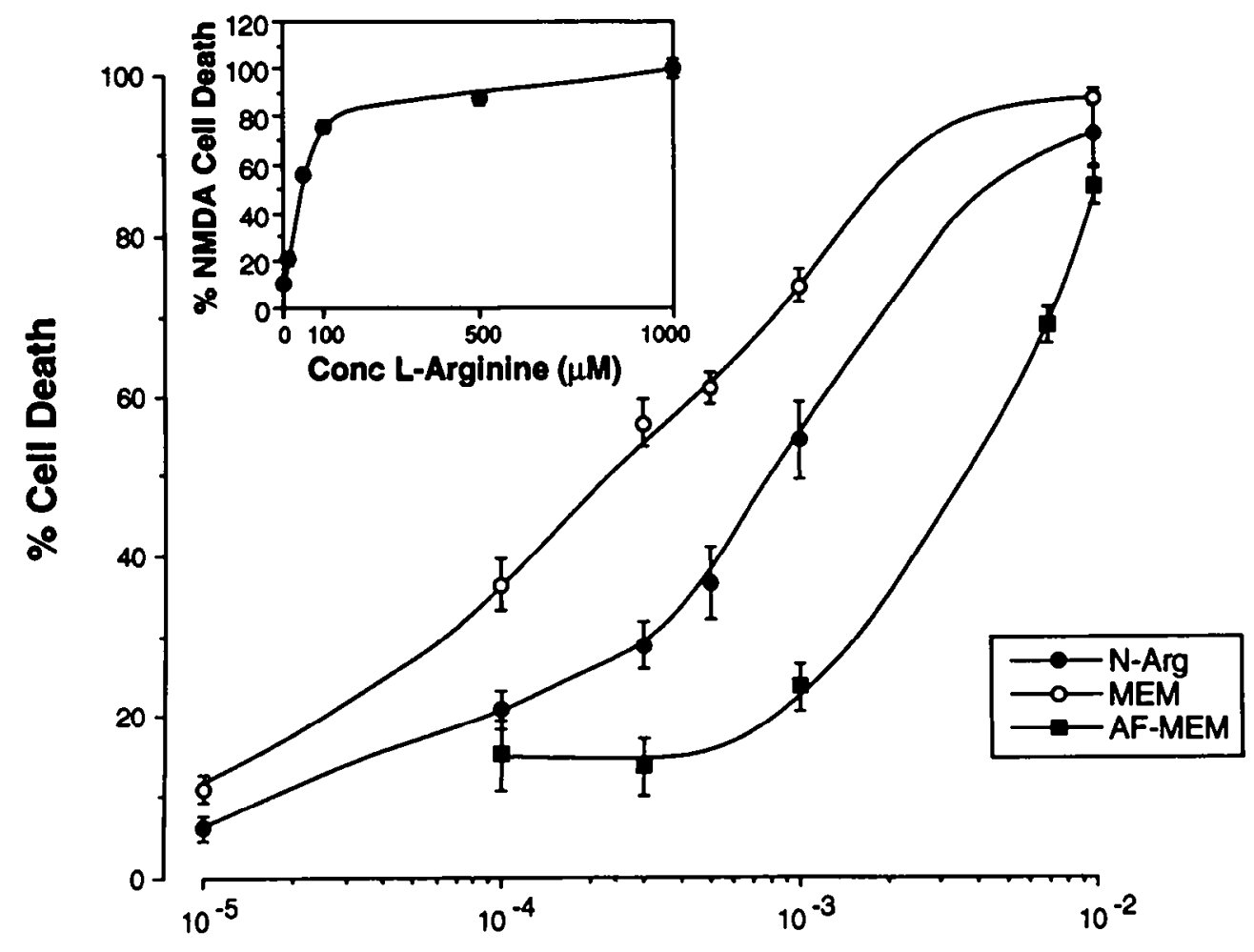

Concentration of NMDA
The methyl ester of N-Arg (NAME) also has an intermediate potency in inhibiting NOS activity and NMDA neurotoxicity, with an $\mathrm{EC}_{\text {so }}$ of $310 \mu \mathrm{M}$. The effects of NMA are stereospecific, as $500 \mu \mathrm{M} N$-methyl-D-arginine provides no protection against NMDA neurotoxicity.

In addition to arginine analogs, NOS can also be inhibited by DPI, which binds the flavin moiety critical to NOS activity (Stuehr et al., 1991). DPI inhibits NMDA toxicity with an $\mathrm{EC}_{50}$ of 30 nм (Fig. 4). DPI also blocks NADPH-diaphorase staining

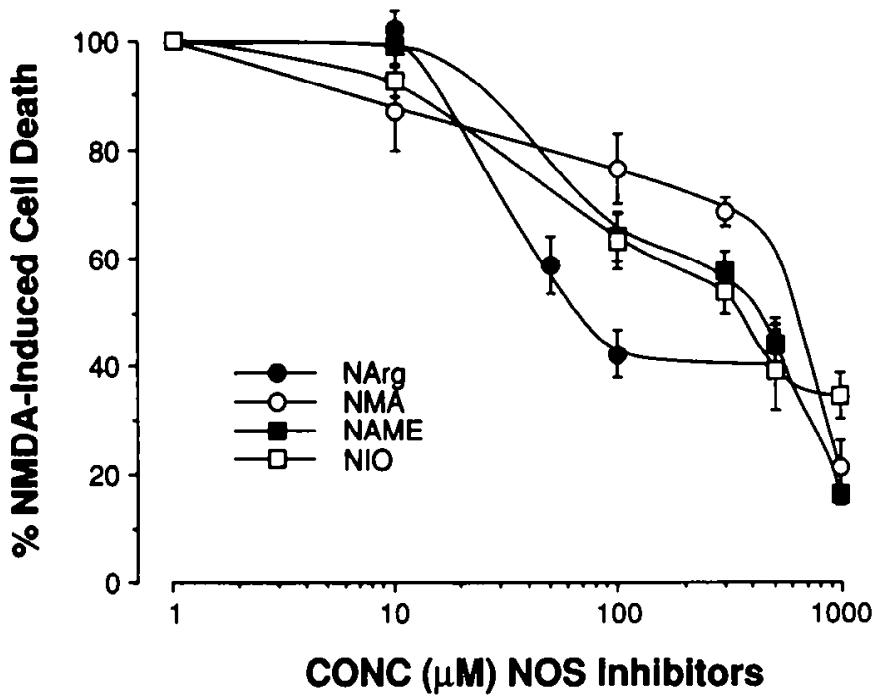

Figure 3. Concentration-response of NOS inhibitors in attenuating $300 \mu \mathrm{M}$ NMDA toxicity. All data points represent the mean \pm SEM of at least two separate experiments in which at least four wells were treated with various agents per experiment and 500-1500 neurons were counted per well. of cortical neurons, an effect not observed with NOS inhibitors that are arginine derivatives.

We also compared effects of NOS inhibitors on neurotoxicity in cultures from different brain regions. In these studics we cvaluated neurotoxicity elicited by glutamate, quisqualate, and kainate in addition to NMDA (Table 1). Glutamate and its three analogs produce substantial neurotoxicity in all three brain regions. In all the brain regions $\mathrm{N}$-Arg produces the most protection against glutamate and NMDA, with somewhat less pro-

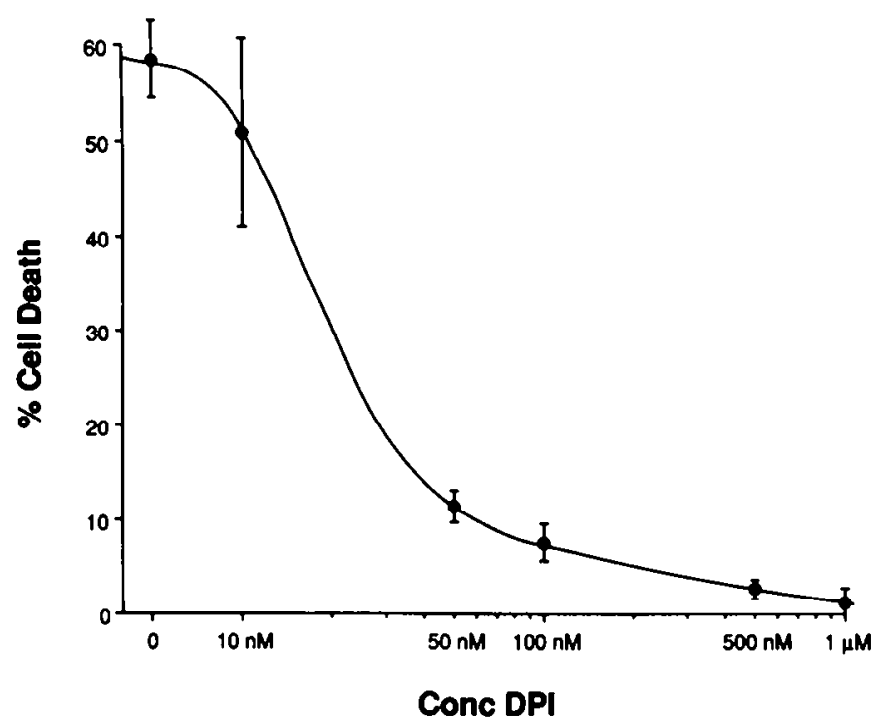

Figure 4. DPI attenuates NMDA neurotoxicity and NADPH-diaphorase staining. All data points represent the mean \pm SEM $(n \geq 8)$ in which approximately $4000-12,000$ neurons were counted for each data point. 


\begin{tabular}{|c|c|c|c|}
\hline Treatment & $\begin{array}{l}\text { Cortex } \\
(\% \text { killed } \pm \text { SEM })\end{array}$ & $\begin{array}{l}\text { Caudate-putamen } \\
(\% \text { killed } \pm \text { SEM) }\end{array}$ & $\begin{array}{l}\text { Hippocampus } \\
\text { ( } \% \text { killed } \pm \text { SEM) }\end{array}$ \\
\hline $500 \mu \mathrm{M}$ glutamate & $49.2 \pm 3.7$ & $74.5 \pm 5.1$ & $58.0 \pm 3.1$ \\
\hline$+100 \mu \mathrm{M}$ N-Arg & $14.5 \pm 3.7^{*}$ & $25.9 \pm 2.9^{*}$ & $2.7 \pm 1.8^{*}$ \\
\hline$+\mathrm{N}-\mathrm{Arg}+1 \mathrm{~mm}$ L-Arg & $50.1 \pm 1.8$ & $74.4 \pm 5.3$ & $52.8 \pm 1.9$ \\
\hline $300 \mu \mathrm{M}$ NMDA & $62.0 \pm 2.7$ & $63.5 \pm 3.0$ & $62.8 \pm 3.2$ \\
\hline$+100 \mu \mathrm{M}$ N-Arg & $20.3 \pm 3.3^{\star}$ & $15.5 \pm 2.4^{*}$ & $18.7 \pm 1.3^{*}$ \\
\hline$+\mathrm{N}-\mathrm{Arg}+1 \mathrm{mM} \mathrm{L-Arg}$ & $64.6 \pm 5.0$ & $60.8 \pm 2.6$ & $56.7 \pm 2.7$ \\
\hline $500 \mu \mathrm{M}$ quisqualate & $60.7 \pm 4.7$ & $64.9 \pm 3.5$ & $60.3 \pm 2.0$ \\
\hline$+500 \mu \mathrm{M}$ N-Arg & $41.5 \pm 4.1^{*}$ & $25.6 \pm 3.4^{*}$ & $49.2 \pm 4.5$ \\
\hline$+\mathrm{N}-\mathrm{Arg}+5 \mathrm{~mm}$ L-Arg & $63.0 \pm 4.5$ & $67.1 \pm 4.0$ & $56.2 \pm 2.2$ \\
\hline $100 \mu \mathrm{M}$ kainate & $83.9 \pm 4.0$ & $85.6 \pm 2.5$ & $83.2 \pm 3.9$ \\
\hline$+500 \mu \mathrm{M}$ N-Arg & $83.0+4.0$ & $67.6 \pm 5.5^{*}$ & $73.9 \pm 4.9$ \\
\hline
\end{tabular}

Data are the means + SEM $(n=6-26)$. Each data point represents a minimum of $4000-12,000$ neurons counted. In some experiments up to 40,000 neurons were counted. Toxicity was assessed by trypan blue exclusion as described in Materials and Methods. Significant overall values were obtained using a one-way between-groups ANOVA. Specific comparisons on all possible pairwise combinations were madc with the Student's $t$ test for independent means; ${ }^{*} p<$ 0.05 .

tection against quisqualate and negligible protection in the cerebral cortex and hippocampus against kainate. In the caudate putàmen, N-Arg produces modest but statistically significant protection against kainate. In all brain regions excess arginine reverses the effects of $\mathrm{N}$-Arg.

The role of calcium, cGMP, and superoxide anion in NMDA neurotoxicity. Large increases in intracellular calcium following NMDA receptor activation have been implicated as a primary mediator of NMDA neurotoxicity (Choi, 1987, 1988; Choi et al., 1988; Meldrum and Garthwaite, 1990). To ascertain whether cell death mediated by increased intracellular calcium involves NO, we examined effects of agents influencing NO disposition following calcium influx (Fig. 5). The calcium ionophore A23187 (30 $\mu \mathrm{M}$, applied for $5 \mathrm{~min}$ ) kills about $70 \%$ of cortical cells, as assessed by trypan blue exclusion $20-24 \mathrm{hr}$ later, similar to the effects of NMDA (Choi, 1987). This neurotoxicity is blocked by N-Arg to a similar extent as the inhibition of NMDA toxicity. Moreover, $\mathrm{L}$-arginine reverses the protective effects of

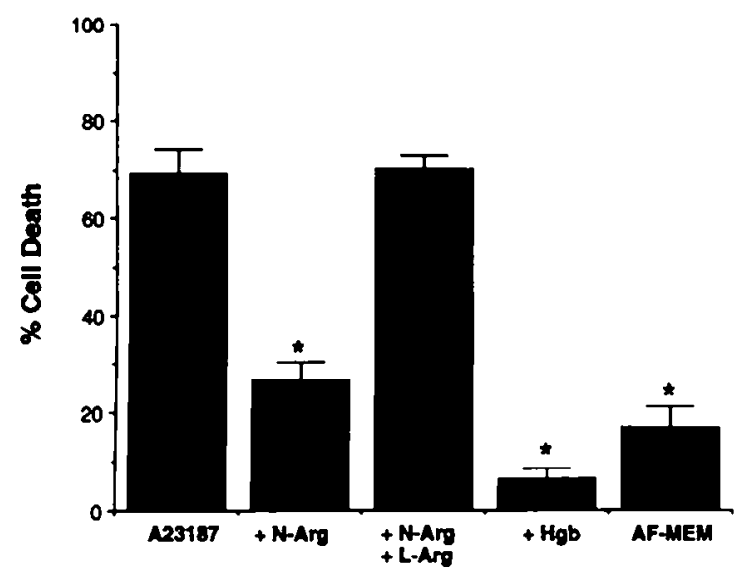

Figure 5. Neurotoxicity elicited by the calcium ionophore A23187. A23187 is affected by the same agents that influence NMDA neurotoxicity. The NOS inhibitor N-Arg $(100 \mu \mathrm{M})$ inhibits A23187 (30 $\mu \mathrm{M})$ neurotoxicity, which can be overcome with excess ( $1 \mathrm{~mm}$ ) substrate, $\mathrm{L}$-arginine ( $\mathrm{L}-\mathrm{Arg}$ ). Toxicity is also attenuated in cultures exposed to 30 $\mu \mathrm{M}$ A23187 in arginine-free media $(A F-M E M)$ or in the presence of 500 $\mu_{\mathrm{M}}$ reduced hemoglobin $(H g b)$. Data are means $\pm \mathrm{SEM}(n \geq 8)$; approximately $4000-12,000$ ncurons were counted for each data point. Toxicity was assessed by trypan blue exclusion. Significance was determined by Student's $t$ test for independent means; ${ }^{*}, p<0.01$.
N-Arg. Reduced hemoglobin, which binds extracellular NO, markedly prevents A23187 toxicity, similar to its protection against NMDA toxicity (V. L. Dawson et al., 1991). A23187 toxicity is also prevented in arginine-free medium.

Calcium activation of NOS involves calmodulin. To evaluate the role of calmodulin in NMDA toxicity, we examined the effects of calmidazolium, a calmodulin antagonist (Table 2). Calmidazolium blocks NMDA neurotoxicity to a similar extent as N-Arg. W7, which binds calmodulin, also blocks NMDA toxicity.

The concentration-response curve for SNP toxicity in cortical cultures parallels its effects in stimulating cGMP concentrations in these cultures (V. L. Dawson et al., 1991). Additionally, the same conditions that modulate NMDA toxicity alter cGMP formation in a similar manner (Dawson et al., 1991a). To ascertain whether cGMP mediates NMDA- and NO-mediated neurotoxicity, we examined the cffects of methylene blue, an inhibitor of guanylyl cyclase (Table 3). Methylene blue fails to block both NMDA- and SNP-induced toxicity. Moreover, 8-bromo-cGMP, a derivative of cGMP that penetrates into cells, has no effect upon neurotoxicity elicited by NMDA or SNP. Exposure to cultures with 8-bromo-cGMP alone does not elicit neurotoxicity. These observations confirm recent findings of Greenberg and collaborators (Lustig et al., 1992a), who explored a variety of guanylyl cyclase inhibitors and cGMP derivatives.

NO can combine with the superoxide anion to form peroxynitrite, which decomposes into the hydroxyl free radical $(\mathrm{OH} \cdot)$ and the nitrogen dioxide free radical $\left(\mathrm{NO}_{2}{ }^{\circ}\right)$, both of which are highly reactive and potentially toxic (Beckman et al., 1990; Radi et al., 1991 a,b). To evaluate the role of the superoxide anion in NMDA and NO neurotoxicity, we examined the effects of su-

\begin{tabular}{ll}
\hline Table 2. Calmodulin inhibitors attenuate NMDA neurotoxicity \\
\begin{tabular}{ll} 
Treatment & \% cell death \pm SEM \\
\hline $300 \mu \mathrm{M}$ NMDA & $63.8 \pm 4.2$ \\
$+10 \mu \mathrm{M}$ calmidazolium & $20.9 \pm 5.0^{*}$ \\
$+200 \mu \mathrm{M} \mathrm{W7}$ & $23.3 \pm 6.6^{*}$
\end{tabular}
\end{tabular}

Data are means \pm SEM $(n \geq 8)$. Each data point represents approximately 4000 12,000 counted neurons. Toxicity was assessed by trypan blue exclusion as described in Materials and Methods. Significance was determined by the Student's $t$ test for independent means; ${ }^{*}, p<0.01$. 
Table 3. Superoxide dismutase but not guanylyl cyclase modulates NMDA and SNP neurotoxicity

\begin{tabular}{ll} 
Treatment & $\begin{array}{l}\text { \%, cell death } \\
( \pm \text { SEM })\end{array}$ \\
\hline $300 \mu \mathrm{M}$ NMDA & $60.6 \pm 5.4$ \\
$+100 \mu \mathrm{M}$ methylene blue & $53.9 \pm 2.2$ \\
+ $1 \mathrm{mM} 8-$-bromo-cGMP & $69.3 \pm 6.4$ \\
+ 100 U SOD & $32.1 \pm 4.0^{*}$ \\
$300 \mu \mathrm{M}$ SNP & $51.3 \pm 3.7$ \\
$+100 \mu \mathrm{M}$ methylene blue & $48.8 \pm 4.9$ \\
$+1 \mathrm{mM}$ 8-bromo-cGMP & $48.4 \pm 4.4$ \\
$+100 \mathrm{U}$ SOD & $18.0 \pm 3.7^{*}$
\end{tabular}

Data are the means \pm SEM $(n \geq 8)$. Each data point represents $4000-12,000$ counted neurons. Toxicity was assessed by trypan blue exclusion as described in Materials and Methods. Significance was determined by Student's $t$ test for independent means; $*$, $p<0.05$.

peroxide dismutase (SOD), an enzyme that scavenges the superoxide anion (Table 3). Addition of SOD to the exposure solution reduces the toxicity elicited by NMDA, SNP, and A23187.

Evidence that NOS neurons are the source of NO that mediates neurotoxicity. NO can be formed by NOS in macrophages and endothelial cells as well as neurons expressing NOS. In the brain, microglia function as macrophages. To determine whether NOS neurons in the cultures are the source of the neurotoxic $\mathrm{NO}$, we took advantage of the differential sensitivity of NOS neurons and other neurons to various toxins (Fig. 6). While about $60 \%$ of the total neuronal population of cortical cultures are killed by $300 \mu \mathrm{M}$ NMDA or $300 \mu \mathrm{M}$ SNP, only about $25 \%$ and $10 \%$, respectively, of NOS neurons die with the two treatments. In contrast, $20 \mu \mathrm{M}$ quisqualate kills less than $20 \%$ of the total neuronal population, but kills about $85-95 \%$ of NOS neurons. These results resemble those of Choi and co-workers, who contrasted the degree of cell death elicited in NADPH-diaphorase-

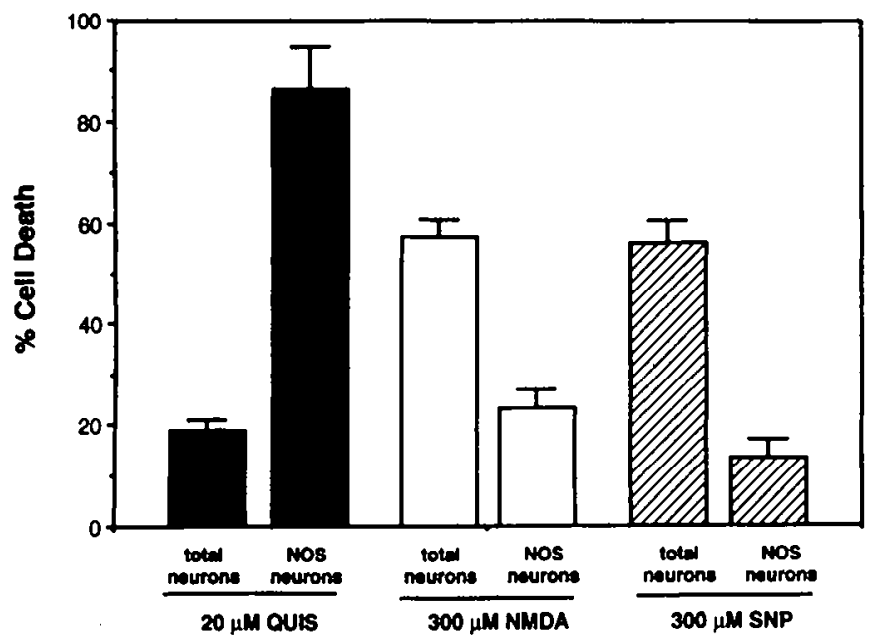

Figure 6. Selective sensitivity of NOS neurons to quisqualate. NOS neurons in primary cortical cultures resist NMDA and SNP neurotoxicity but are more sensitive than other neurons to quisqualate. Lowdose, $20 \mu \mathrm{M}$ quisqualate (QUIS) produces substantial loss of NOS neurons without much decrease in the total cell population. The total cell counts include NOS neurons. NMDA $(300 \mu \mathrm{M})$ and SNP $(300 \mu \mathrm{M})$ elicit more than $60 \%$ cell death in the total neuronal population but only $25 \%$ and $13 \%$ loss of NOS neurons, respectively. Data are means \pm SEM ( $n$ $\geq 8$ ).

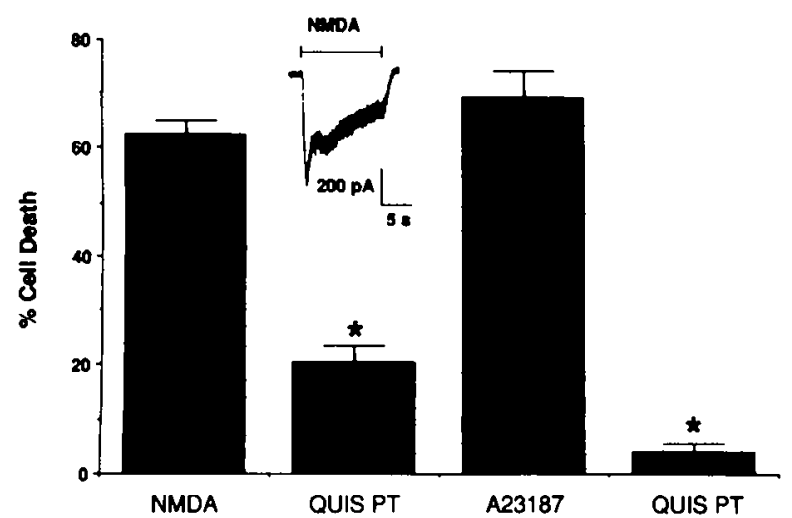

Figure 7. Selectively killing NOS neurons prior to NMDA or A23187 exposure reduces toxicity. Treating primary cortical neurons with 20 $\mu \mathrm{M}$ quisqualate, $24 \mathrm{hr}$ prior to treating these neurons with $300 \mu \mathrm{M}$ NMDA or $30 \mu \mathrm{M}$ A23187 (QUIS PT), reduces NMDA neurotoxicity $71 \%$ and A23187 neurotoxicity $94 \%$. Neurons in sister cultures treated with 20 $\mu \mathrm{M}$ quisqualate still produce currents on application of $200 \mu \mathrm{M}$ NMDA (trace inset). Data are means $\pm \operatorname{SEM}(n \geq 8)$. Significance was determined by Student's $t$ test for independent means; ${ }^{*}, p<0.01$.

positive neurons versus the total neuronal population following exposure to graded concentrations of NMDA or quisqualate (Koh et al., 1986; Koh and Choi, 1988). NOS neurons are also resistant to the toxic effects of exogenously applied NO (Fig. 6). We examined the neurotoxicity of $300 \mu \mathrm{M}$ NMDA in cultures treated $24 \mathrm{hr}$ earlier with $20 \mu \mathrm{M}$ quisqualate, a concentration that destroys $85-95 \%$ of NOS neurons (Fig. 7). In these cultures NMDA toxicity is profoundly attenuated. In sister cultures pretreated in the same manner with $20 \mu \mathrm{M}$ quisqualate, $200 \mu \mathrm{M}$ NMDA still clicits calcium currents, indicating the persistence of functional NMDA receptors. Toxicity elicited by the calcium ionophore A23187 is also attenuated by quisqualate pretreatment (Fig. 7). In addition, a critical number of NOS neurons (approximately 100 NOS-positive cells per $15 \mathrm{~mm}$ well) were required to observe an NO component to NMDA neurotoxicity (data not shown). These experiments strongly implicate NOS neurons as the source of NO that mediates NMDA toxicity.

To examine the role of NOS neurons in NMDA toxicity by another paradigm, we evaluated NMDA toxicity at different days in culture while monitoring the percentage of cells that stain positive for NADPH-diaphorase (Fig. 8). NMDA toxicity is not evident for the first $16 \mathrm{~d}$ in culture, and then develops gradually, reaching full effects at $20 \mathrm{~d}$ in culture. NADPH-diaphorase staining of the cells displays a virtually identical time course. Despite the absence of NMDA toxicity in early stages of the culture, NMDA-mediated calcium currents are evident at day 7 and day 14, though they are somewhat smaller than at day 21 . Although young cultures are resistant to NMDA toxicity, they are sensitive to $300 \mu \mathrm{M}$ SNP, which produces the same extent of cell killing at 7 and $14 \mathrm{~d}$ as at $21 \mathrm{~d}$ (data not shown).

Inducible macrophage NOS activity is calcium independent, while neuronal NOS requires added $\mathrm{Ca}^{2+}$ (Marletta, 1989). We assessed a potential role for microglial, inducible NOS by examining whether there was any calcium-independent NOS catalytic activity $2,4,8$, and $24 \mathrm{hr}$ after a $5 \mathrm{~min}$ application of NMDA. Despite the presence of abundant calcium-dependent NOS catalytic activity, no appreciable calcium-independent NOS catalytic activity was detected (data not shown). In addition, application of LPS and $\gamma$-interferon, potent inducers of mac- 


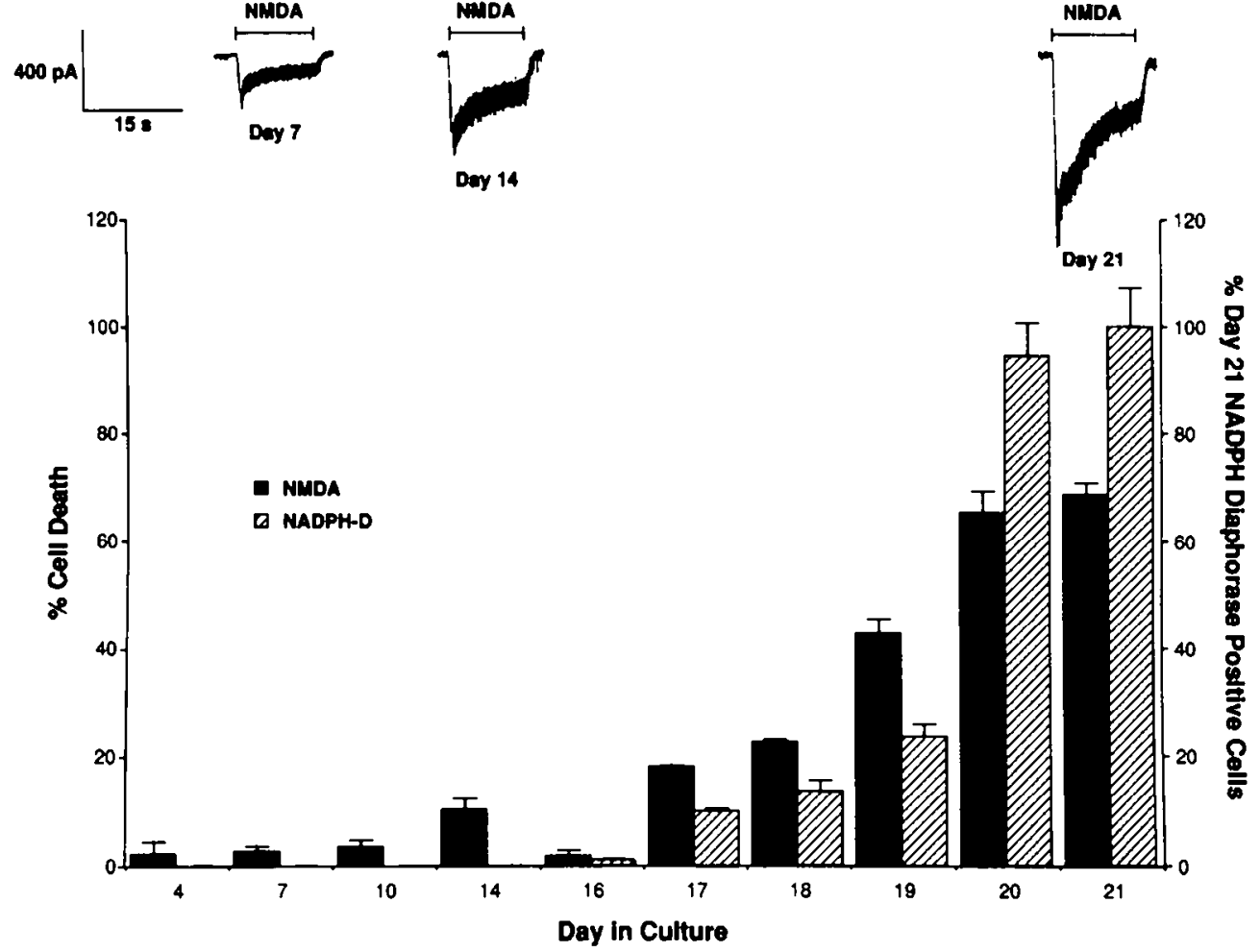

Figure 8. The development of NMDA neurotoxicity corresponds with the appearance of NOS neurons. After dissociated cortical cells were plated (day 0 ), cells were periodically assessed for NMDA neurotoxicity and NADPHdiaphorase stain. Neurotoxicity and NADPH-diaphorase staining were first observed on day 17 in culture, with development of full expression by day 20 . NMDA-induced currents were observed as early as day 7 in culture. Neurotoxicity to $300 \mu \mathrm{M}$ SNP was observed at day 7 and did not vary over time. Data are means \pm SEM $(n \geq 9)$. rophage NOS, fails to induce a calcium-independent NOS. Thus, neuronal NOS seems to be the primary source of neurotoxic NO in primary cortical cultures.

Because NOS occurs in only $1-2 \%$ of cerebral cortical cells, we might ask how NO is able to kill the majority of cells in cultures. To examine this question, we conducted both darkand bright-field microscopy of sections of intact adult rat cerebral cortex (Fig. 9) and cortical cultures (Fig. 10 and data not shown). While the number of NOS cells in a given field may be few, processes of the cells ramify extensively to cover virtually all the surface of the culture (Fig. 10). Since the extensive ramification of NOS processes in culture is difficult to illustrate, we show the extensive amount of NOS processes in a tissuc section of intact adult rat cerebral cortex (Fig. 9). Dead cells following NMDA treatment occur in patches. These patches are largely concentrated about processes and cell bodics of NOS neurons (Fig. 10).

\section{Discussion}

In the present study we confirm and extend our previous observations that NO is responsible, at least in part, for NMDAtype glutamate neurotoxicity. The relative potencies of several NOS inhibitors in blocking neurotoxicity parallel their potencies as NOS inhibitors. The ability of NOS inhibitors to protect against NMDA neurotoxicity in brain cultures as well as in brain slices has now been confirmed by several groups (Izumi et al., 1992; Lustig et al., 1992b; Moncada et al., 1992; Wallis et al., 1992). NO has also been implicated in neuronal injury in intact animals, as $\mathrm{N}$-Arg ( $1 \mathrm{mg} / \mathrm{kg}$, i.p., repeated doses) blocks neurotoxicity elicited by ligation of the middle cerebral artery more effectivcly than the noncompetitive NMDA antagonist MK801 (Nowicki ct al., 1991). Additionally, N-Arg is completely neuroprotective against focal stroke in the 7-d-old rat (Trifiletti, 1992). In one report the NOS inhibitor N-Arg did not block neuronal injury in whole rat brain cultures (Demerle-Pallardy et al., 1991). Whether the use of whole brain cultures or other factors accounted for the failure of NOS inhibitors to block neurotoxicity is unclear.

Besides the cerebral cortex, we observed blockade of toxicity by NOS inhibitors in caudate-putamen and hippocampal cultures. N-Arg blocks glutamate and NMDA toxicity to a greater extent than quisqualate toxicity. At the concentrations of quisqualate and the mode of application that we have employed, it is likely that quisqualate may act in part via NMDA receptors (Koh ct al., 1990), which may account for the portion of quisqualate toxicity prevented by $\mathrm{N}$-Arg. N-Arg does not block kainate toxicity in the cerebral and hippocampal cultures, which fits with observations of Coyle and associates (Puttfarcken et al., 1992) that kainate toxicity involves free radicals and not NO. N-Arg does prevent a portion of kainate neurotoxicity in the striatal cultures. Perhaps kainate-sensitive calcium channels (Murphy et al., 1987) cause excessive release of NO from NOS neurons and account in part for the neuronal injury associated with kainate in the caudate-putamen. Intcrestingly, NOS inhibitors do not prevent glutamate neurotoxicity in cerebellar granule cells (Puttfarcken et al., 1992). All cerebellar granule cells are enriched in NOS (Bredt et al., 1991). Their resistance to NMDA toxicity fits with our observation that NOS neurons are uniquely resistant to NMDA and SNP toxicity. On the other hand, R. J. Miller and colleagues (personal communication) have shown that in cultures of cerebellar enriched Purkinje cells, kainate-induced killing of cerebellar Purkinje cells, which lack NOS, is attenuated by NOS inhibitors.

Application of SNP, which spontaneously releases NO, elicits cell death in a concentration- and time-dependent fashion that parallels NMDA toxicity, observations also made by Chen et al. (1991) in striatal cultures. SNP elicits neuronal injury in intact animals when injected directly into the hippocampus 


\section{NOS}
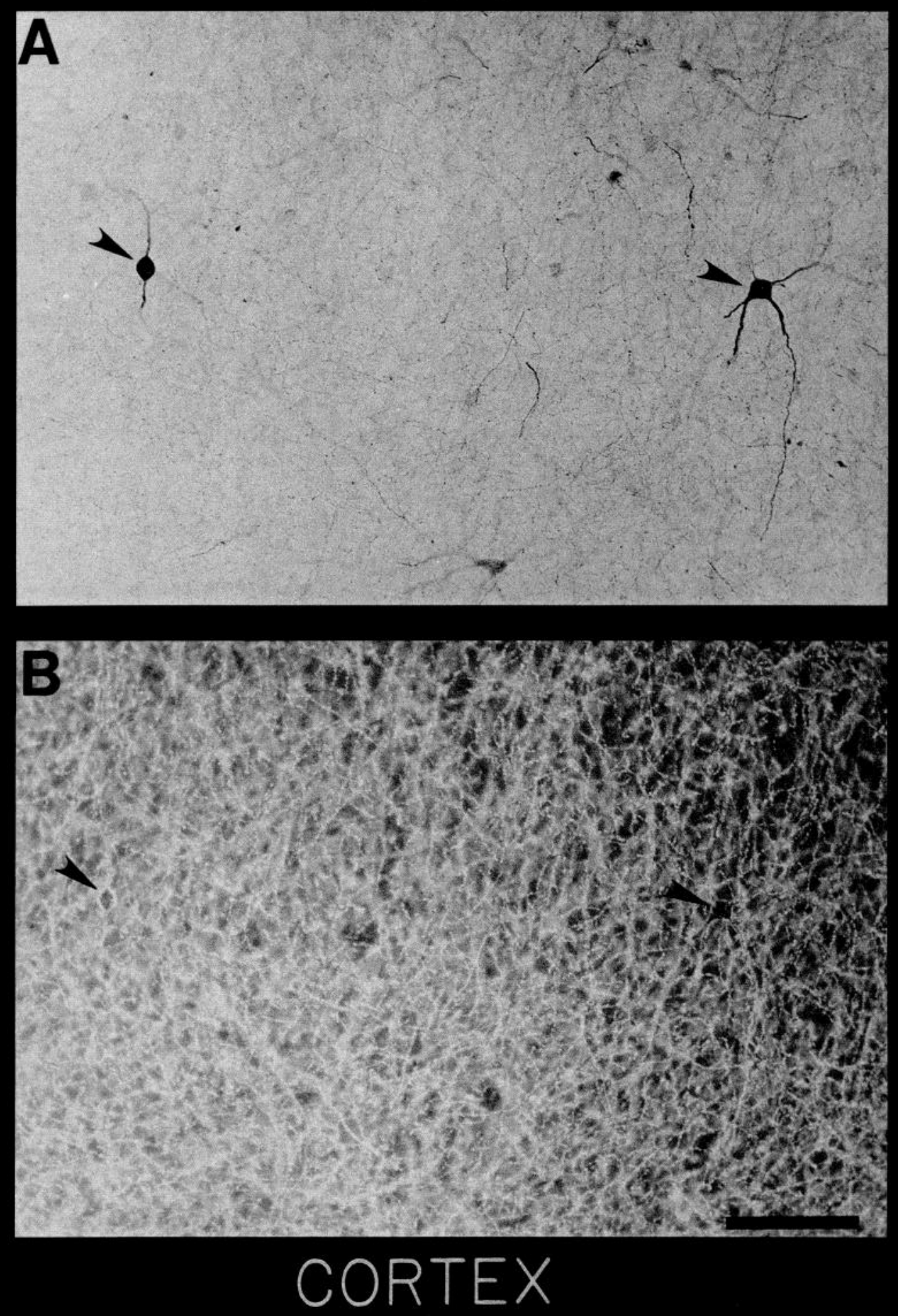

Figure 9. NOS neurons and processes in cerebral cortex. $A$, Bright-field photomicrograph illustrating the distribution and density of NOS neurons (arrowheads) in the cerebral cortex from intact adult rat brain. B. Dark-field photomicrograph of $A$, illustrating the dense plexus of NOS fibers throughout the cortex. Scale bar, $100 \mu \mathrm{m}$. 


\section{CORTEX}
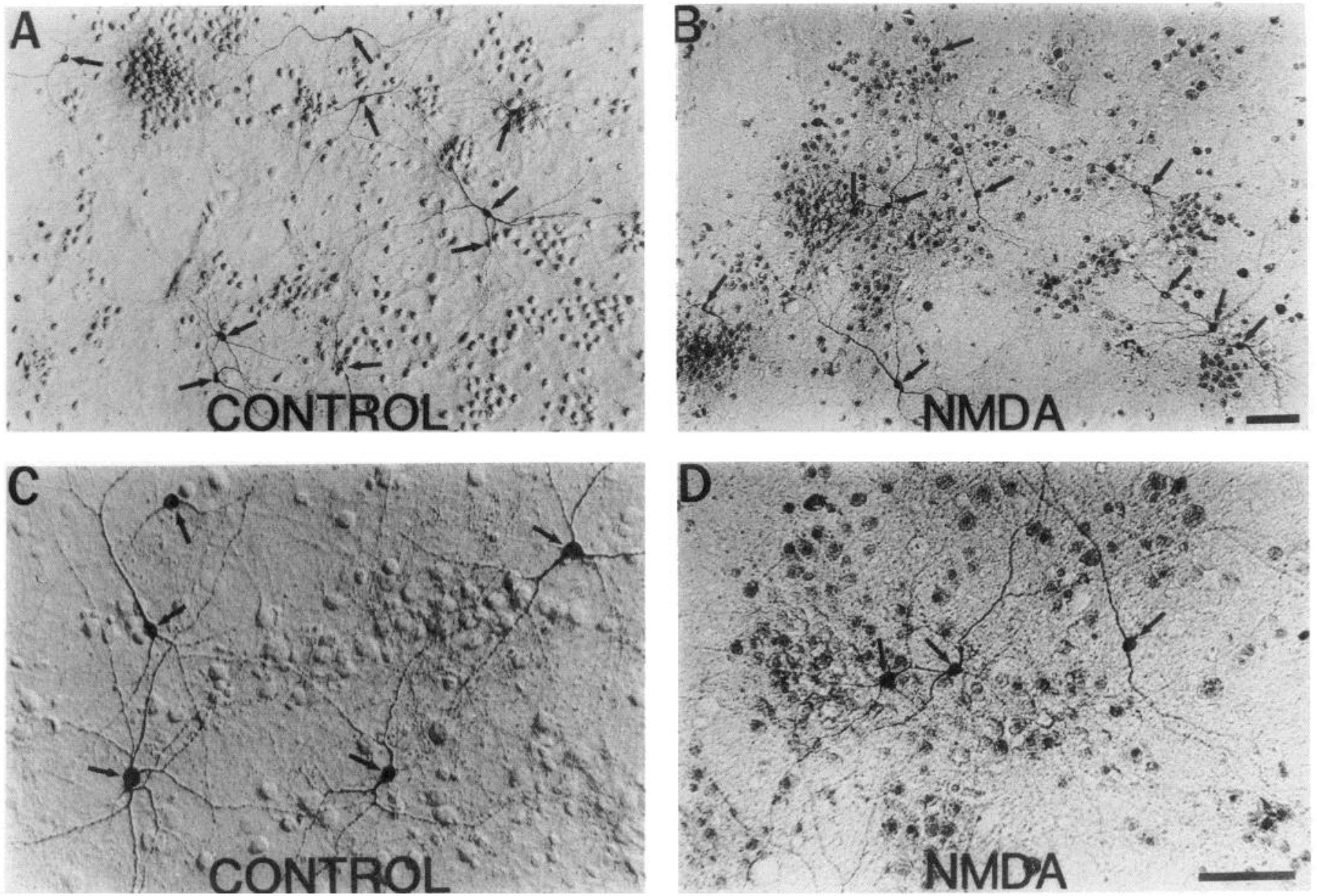

Figure 10. NMDA kills neurons within the vicinity of NOS neurons and/or processes. $A$, Low-power Hoffman modulation photomicrography of NOS neurons (arrows) in cortical cultures. B, NMDA kills neurons in the vicinity of NOS neurons. Dead neurons appear black in these photomicrographs. $C$, High-power view of cortical cultures stained with anti-NOS antibody. $D$, High-power view of NMDA neurotoxicity. Scale bar, $100 \mu \mathrm{m}$.

(Loiacono and Beart, 1992). $\mathrm{K}_{4}\left[\left(\mathrm{Fe}(\mathrm{CN})_{6}\right]\right.$, which elicits the same nonspecific effects as the $\mathrm{Fe}\left(\mathrm{CN}_{5}\right)^{2-}$ moiety of SNP, does not cause neuronal injury. Several other NO releasers also cause neuronal injury both in primary cultures (Chen et al., 1991; Lustig et al., 1992b) and in intact animals (Smith et al., 1991). In addition, $40 \mathrm{~nm}$ authentic NO can cause cell death in hippocampal cultures (O'Dell et al., 1991). Thus, whether NO is from exogenous sources, such as SNP or other NO releasers, or is endogenously generated, it may function as a neurotoxin under conditions of excessive NO production or release.

Calcium has been implicated as a major mediator of glutamate neurotoxicity (Choi, 1988; Meldrum and Garthwaite, 1990). However, some evidence indicates that intracellular calcium levels do not directly correlate with such toxicity (Michaels and Rothman, 1990; Dubinsky and Rothman, 1991). For instance, brief $(5 \mathrm{~min})$ glutamate exposure elicits a transient elevation in intracellular calcium that recovers to the basal level in the majority of neurons in culture (Randall and Thayer, 1992). Despite normal intracellular calcium levels after the initial glutamate exposure, irreversible processes are started that no longer require a sustained elevation of intracellular calcium (Randall and Thayer, 1992). These early irreversible processes lead to the initiation of "delayed neurotoxicity" associated with calcium overload (Choi, 1988, 1990; Randall and Thayer, 1992). Our studies indicate that activation of NOS leads to these lethal processes, as neurotoxicity directly elicited by a calcium ionophore A23187 is mediated via NO, being blocked by N-Arg, hemoglobin, and arginine-free medium. Moreover, NMDA toxicity is blocked by calmodulin antagonists, indicating that the toxicity elicited by calcium involves calmodulin and, presumably, the calmodulin-induced activation of NOS. In contrast to the crucial role for calcium and calmodulin, cGMP does not appear to mediate the toxicity directly. In our experiments as well as those of Greenberg and colleagues (Lustig et al., 1992a), the guanylyl cyclase inhibitor methylene blue does not block neurotoxicity, and 8-bromo-cGMP does not influence toxicity. Garthwaite and Garthwaite (1988) obtained evidence that cGMP may protect against neurotoxicity in cerebellar slices.

Evidence for participation of superoxide anions in neurotoxicity elicited by NMDA, the calcium ionophore, as well as the direct generation of NO from SNP is evident from the protective effects of SOD. The importance of superoxide anions in NMDA neurotoxicity is emphasized by findings that cortical cultures from transgenic mice overexpressing SOD are resistant to NMDA 
neurotoxicity (Chan et al., 1990) and these same animals are relatively resistant to focal ischemia (Kinouchi et al., 1991). SOD protection might relate to superoxides directly generated by NOS, as purified NOS dircctly forms superoxide anions (Pou et al., 1992). The combination of the superoxide anion and NO gives rise to peroxynitrite, which in turn decomposes into $\mathrm{OH}^{\cdot}$ and $\mathrm{NO}_{2} \cdot$ free radicals that are highly reactive and might be the final common mediators of NO toxicity (Beckman et al., 1990; Beckman, 1991; Radi et al., 199 la,b; Dawson et al., 1992, 1993). Extracellular SOD would not be cxpected to penetrate cells, suggesting that the superoxide anion may be releascd upon glutamate exposure. However, Bennett and colleagues (Saez et al., 1987) have shown that exogenously administered ${ }^{125}$ I-labcled SOD can attain high intracellular levels under depolarizing conditions. Both NO (Lei et al., 1992; Manzoni et al., 1992b) and the superoxide anion (Aizenman et al., 1989, 1990) block both NMDA receptor currents and the associated increase in intracellular calcium. Thus, both potential toxic agents might exert feedback inhibition on NMDA receptors under physiologic conditions. With excessive release of both $\mathrm{NO}$ and the superoxide anion, normal regulatory mechanisms might be overwhelmed, leading to cell death. As suggested by Lei et al. (1992), NO is necessary but not sufficient for neuronal injury and is toxic only in the presence of other factors, such as the superoxide anion.

Why NOS neurons are selectively resistant to various forms of neurotoxicity is not known. SOD could, in principle, protect these cells against such toxicity. Conceivably NOS neurons are enriched in SOD, which would account in part for their resistance to toxicity. In the cerebral cortex and in the caudateputamen all somatostatin neurons are positive for NOS (T. M. Dawson et al., 1991). Inagaki et al. (1991) have observed high levels of SOD staining in somatostatin neurons of the caudateputamen. In the caudate-putamen large ACh-containing interneurons as well as NADPH-diaphorase neurons are resistant to degeneration in Huntington's disease (Ferrante et al., 1985), and though the ACh-containing interneurons do not stain for NOS (T. M. Dawson et al., 1991), these cells do display high densities of SOD staining (Inagaki et al., 1991).

Using several experimental approaches, we have established that the NO that mediates neurotoxicity derives from NOS neurons. Thus, destruction of $85-95 \%$ of NOS neurons but less than $10-20 \%$ of the total neuronal population in cortical cultures attenuates the ability of NMDA to elicit toxicity. Moreover, NMDA toxicity in cortical cultures does not appear until day 17 and peaks at day 20 , coincident with the development of NOS-positive cells. Finally, although they comprise only approximately $1-2 \%$ of the total neuronal population, NOS neurons have extensive processes and ramify to influence the majority of neurons in culture as well as in intact animals. Thus, under conditions of excessive NO production, this small population of neurons could kill a large population of surrounding neurons.

\section{References}

Aizenman E, Lipton SA, Loring RH (1989) Selective modulation of NMDA responses by reduction and oxidation. Neuron 2:1257-1263. Aizenman E, Hartnett KA, Reynolds IJ (1990) Oxygen free radicals regulate NMDA receptor function via a redox modulatory site. Neuron $5: 841-846$

Beal MF, Kowall NW, Ellison DW, Mazurek MF, Swartz KJ, Martin JB (1986) Replication of the neurochemical characteristics of Huntington's disease by quinolinic acid. Nature 321:168-171.
Beckman JS (1991) The doubled-edge role of nitric oxide in brain function and superoxide-mediated injury. J Dev Physiol 15:53-59.

Beckman JS, Beckman TW, Chen J, Marshall PA, Freeman BA (1990) Apparent hydroxyl radical production by peroxynitrite: implications for endothelial injury from nitric oxide and superoxide. Proc Natl Acad Sci USA 87:1620-1624.

Bredt DS, Snyder SH (1989) Nitric oxide mediates glutamate-linked cnhancement of cGMP levels in the cerebellum. Proc Natl Acad Sci USA 86:9030-9033.

Bredt DS, Snyder SH (1990) Isolation of nitric oxide synthetase, a calmodulin-requiring enzyme. Proc Natl Acad Sci USA 87:682-685.

Bredt DS, Hwang PM, Snyder SH (1990) Localization of nitric oxide synthase indicating a neural role for nitric oxide. Nature 347:768770.

Bredt DS, Glatt CE, Hwang PM, Fotuhi M, Dawson TM, Snyder SH (1991) Nitric oxide synthase protein and mRNA are discretely localized in neuronal populations of the mammalian CNS together with NADPH diaphorase. Neuron 7:615-624.

Chan PH, Chu L, Chen SF, Carlson EJ, Epstein CJ (1990) Reduced neurotoxicity in transgenic mice overexpressing human copper-zincsuperoxide dismutase. Stroke 21:80-82.

Chen J, Chang B, Williams M, Murad F (1991) Sodium nitroprusside degenerates cultured rat striatal neurons. Neuroreport 2:121-123.

Choi DW (1987) Ionic dependence of glutamate neurotoxicity. J Neurosci $7: 369-379$.

Choi DW (1988) Glutamate ncurotoxicity and diseases of the nervous system. Neuron 1:623-634.

Choi DW (1990) Cerebral hypoxia: some new approaches and unanswered questioins. J Neurosci 10:2493-2501.

Choi DW, Koh J, Peters S (1988) Pharmacology of glutamate neurotoxicity in cortical cell culture: attenuation by NMDA antagonists. J Neurosci 8:185-196.

Dawson TM, Bredt DS, Fotuhi M, Hwang PM, Snyder SH (1991) Nitric oxide synthase and neuronal NADPH diaphorase are identical in brain and peripheral tissues. Proc Natl Acad Sci USA 88:77977801 .

Dawson TM, Dawson VL, Snyder SH (1992) A novel neuronal messenger molecule in brain: the free radical, nitric oxide. Ann Neurol 32:297-311.

Dawson TM, Dawson VL, Snyder SH (1993) Nitric oxide as a mediator of neurotoxicity. Natl Inst Drug Abuse Res Monogr Ser, in press.

Dawson VL, Dawson TM, London ED, Bredt DS, Snyder SH (1991) Nitric oxide mediates glutamate neurotoxicity in primary cortical culture. Proc Natl Acad Sci USA 88:6368-6371.

Demerle-Pallardy C, Lonchampt MO, Chabrier PE, Braquet P (1991) Absence of implication of L-arginine/nitric oxide pathway on neuronal cell injury induced by $\mathrm{L}$-glutamate or hypoxia. Biochem Biophys Res Commun 181:456-464.

Demirgoren S, Majewska MD, Spivak CE, London ED (1991) Receptor binding and clectrophysiological effects of dehydroepiandrosterone sulfate, an antagonist of the $\mathrm{GABA}_{\mathrm{A}}$ receptor. Neuroscience 45:127-135.

Dubinsky JM, Rothman SM (1991) Intracellular calcium concentrations during "chemical hypoxia" and exitotoxic neuronal injury. J Neurosci 11:2545-2551.

East SJ. Batchelor AM, Garthwaite J (1991) Selective blockade of $N$-methyl-D-aspartate receptor function by the nitric oxide donor, nitroprusside. Eur J Pharmacol 209:119-121.

Fcrrante RJ, Kowall NW, Beal MF, Richardson EP Jr, Bird ED, Martin JB (1985) Selective sparing of a class of striatal neurons in Huntington's disease. Science 230:561-563.

Furchgott RF (1990) The 1989 Ulf von Euler lecture. Studies on endothelium-dependent vasodilation and the endothelium-derived relaxing factor. Acta Physiol Scand 139:257-270.

Garthwaite G, Garthwaite J (1988) Cyclic GMP and cell death in rat cerebellar slices. Neuroscience 26:321-326.

Garthwaite J (1991) Glutamate, nitric oxide and cell-cell signalling in the nervous system. Trends Neurosci 14:60-67.

Hamill OP, Marty A, Neher E, Sakmann B, Sigworth FJ (1981) Improved patch-clamp techniques for high-resolution current recording from cells and cell-free membrane patches. Pfluegers Arch 391:85100 .

Hibbs JB Jr, Taintor RR, Vavrin Z (1987) Macrophage cytotoxicity: 
role for $\mathrm{L}$-arginine deaminase and imino nitrogen oxidation to nitrite. Science 235:473-476.

Hope BT, Michael GJ, Knigge KM, Vincent SR (1991) Neuronal NADPH diaphorase is a nitric oxide synthase. Proc Natl Acad Sci USA 88:2811-2814.

Ignarro LJ (1990) Biosynthesis and metabolism of endothelium-derived nitric oxide. Annu Rev Pharmacol Toxicol 30:535-560.

Inagaki S, Suzuki K, Taniguchi N, Takagi H (1991) Localization of Mn-superoxide dismutase (Mn-SOD) in cholinergic and somatostatin-containing neurons in the rat neostriatum. Brain Res 549:174-177.

Izumi Y, Benz AM, Clifford DB, Zorumski CF (1992) Nitric oxide inhibitors attenuatc $N$-methyl-D-aspartate excitotoxicity in rat hippocampal slices. Neurosci Lett 135:227-230.

Kiedrowski L, Manev H, Wroblewski JT (1991) Inhibition of glutamate-induced cell death by sodium nitroprusside is not mediated by nitric oxide. Neuropharmacology 30:1241-1243.

Kiedrowski L, Costa E, Wroblewski JT (1992) Sodium nitroprusside inhibits $N$-methyl-D-aspartate-evoked calcium influx via a nitric oxide- and cGMP-independent mechanism. Mol Pharmacol 41:779784.

Kinouchi H, Epstein CJ, Mizui T, Carlson E, Chen SF, Chan PH (1991) Attenuation of focal cerebral ischemic injury in transgenic mice overexpressing CuZn superoxide dismutase. Proc Natl Acad Sci USA 88: $11158-11162$.

Koh J-Y, Choi DW (1988) Vulnerability of cultured cortical neurons to damage by exocitotoxins: differential susceptibility of neurons containing NADPH-diaphorasc. J Ncurosci 8:2153-2163.

Koh $\mathrm{J}-\mathrm{Y}$, Peters S, Choi DW (1986) Neurons containing NADPHdiaphorase are selectively resistant to quinolinate toxicity. Science 234:73-76

Koh J-Y, Goldberg MP, Hartley DM, Choi DW (1990) Non-NMDA receptor-mediated neurotoxicity in cortical culture. J Neurosci 10: 693-705.

Lei SZ, Pan Z-H, Aggarwal SK, Chen H-SV, Hartman J, Sucher NJ, Lipton SA (1992) Effect of nitric oxide production on the redox modulatory site of the NMDA reccptor-channel complex. Neuron 8:1087-1099.

Loiacono RE, Beart PM (1992) Hippocampal lesions induced by microinjection of the nitric oxide donor nitroprusside. Eur J Pharmacol 216:331-333.

Lustig HS, von Brauchitsch KL, Chan J, Greenberg DA (1992a) Cyclic GMP modulators and excitotoxic injury in cerebral cortical cultures. Brain Res 577:343-346.

Lustig HS, von Brauchitsch KL, Chan J, Greenberg DA (1992b) Ethanol and excitotoxicity in cultured cortical neurons: differential sensitivity of $N$-methyl-D-aspartate and sodium nitroprusside toxicity. $\mathbf{J}$ Neurochem 59:2193-2200.

Manzoni O, Prezeau L, Desagher S, Sahuquet A, Sladeczek F, Bockaert J. Fagni L (1992a) Sodium nitroprusside blocks NMDA receptors via formation of ferrocyanide ions. Neuroreport 3:77-80.

Manzoni O, Prezeau L, Marin P, Deshager S, Bockaert J, Fagni L (1992b) Nitric oxide-induced blockade of NMDA receptors. Neuron 8:653-662.

Marletta MA (1989) Nitric oxide: biosynthesis and biological significance. Trends Biochem Sci 14:488-492.

Martin W, Villani GM, Jothianandan D, Furchgott RF (1985) Selective blockade of endothelium-dependent and glyceryl trinitrate-induced relaxation by hemoglobin and by methylene blue in the rabbit aorta. J Pharmacol Exp Ther 232:708-716.

McCall TB, Feelisch M, Palmer RMJ, Moncada S (1991) Identification of $N$-iminoethyl-L-ornithine as an irreversible inhibitor of nitric oxide synthase in phagocytic cells. Br J Pharmacol 102:234-238.
Meldrum B, Garthwaite J (1990) Excitatory amino acid neurotoxicity and ncurodegenerative disease. Trends Pharmacol Sci 11:379-387.

Michaels RL, Rothman SM (1990) Glutamate neurotoxicity in vitro: antagonist pharmacology and intracellular calcium concentrations. J Neurosci 10:283-292.

Moncada C, Lekieffre D, Arvin B, Meldrum B (1992) Effect of NO synthase inhibition on NMDA- and ischaemia-induced hippocampal lesions. Neuroreport 3:530-532.

Moncada S, Palmer RMJ, Higgs EA (1991) Nitric oxide: physiology, pathophysiology and pharmacology. Pharmacol Rev 43:109-142.

Murphy SN, Thayer SA, Miller RJ (1987) The effects of excitatory amino acids on intracellular calcium in single mouse striatal neurons in vitro. J Neurosci 7:4145-4158.

Nowicki JP, Duval D, Poignet H, Scatton B (1991) Nitric oxide mediates neuronal death after focal cerebral ischemia in the mouse. Eur J Pharmacol 204:339-340.

O'Dell TJ, Hawkins RD, Kandel ER, Arancio O (1991) Tests of the roles of two diffusible substances in long-term potentiation: evidence for nitric oxide as a possible carly retrograde messenger. Proc Natl Acad Sci USA 88:11285-11289.

Pou S, Pou WS, Bredt DS, Snyder SH, Rosen GM (1992) Generation of superoxide by purified brain nitric oxide synthase. J Biol Chem 267:24173-24176.

Puttfarcken PS, Lyons WE, Coyle JT (1992) Dissociation of nitric oxide generation and kainate-mediated neuronal degeneration in primary cultures of rat cerebellar granule cells. Neuropharmacology 31 : 565-575.

Radi R, Beckman JS, Bush KM, Freeman BA (1991a) Peroxynitriteinduced membrane lipid peroxidation: the cytotoxic potential of superoxide and nitric oxide. Arch Biochem Biophys 288:481-487.

Radi R, Beckman JS, Bush KM, Freeman BA (199lb) Peroxynitritc oxidation of sulfhydryls. The cytotoxic potential of superoxide and nitric oxide. J Biol Chem 266:4244-4250.

Randall RD, Thayer SA (1992) Glutamate-induced calcium transient triggers delayed calcium overload and neurotoxicity in rat hippocampal neurons. J Neurosci 12:1882-1895.

Saez JC, Kessler JA, Bennett MVL, Spray DC (1987) Superoxide dismutase protects cultured neurons against death by starvation. Proc Natl Acad Sci USA 84:3056-3059.

Sessa WC, Hecker M, Mitchell JA, Vane JR (1990) The metabolism of $\mathrm{L}$-arginine and its significance for the biosynthesis of endotheliumderived relaxing factor: $L$-glutamine inhibits the generation of $\mathrm{L}$-arginine by cultured endothelial cells. Proc Natl Acad Sci USA 87:86078611.

Smith RP, Louis CA, Kruszyna R, Kruszyna H (1991) Acute neurotoxicity of sodium axide and nitric oxide. Fundam Appl Toxicol 17:120-127.

Snyder SH (1992) Nitric oxide: first in a new class of neurotransmitters? Science 257:494-496

Snyder SH, Bredt DS (1991) Nitric oxide as a neuronal messenger. Trends Pharmacol Sci 12:125-128.

Stuehr DJ, Fasehun OA, Kwon NS, Gross SS, Gonzalez JA, Levi R, Nathan CF (1991) Inhibition of macrophage and endothelial cell nitric oxide synthase by diphenyleneiodonium and its analogs. FASEB J 5:98-103.

Trifiletti RR (1992) Neuroprotective effects of $\mathrm{N}^{\mathrm{i}}$-nitro-L-arginine in focal stroke in the 7-day-old rat. Eur J Pharmacol 218:197-198.

Wallis RA, Panizzon K, Wasterlain CG (1992) Inhibition of nitric oxide synthase protects against hypoxic neuronal injury. Neuroreport $3: 645-648$. 